\title{
Devosia yakushimensis sp. nov., isolated from root nodules of Pueraria lobata (Willd.) Ohwi
}

Correspondence Vernans V. Bautista vvbver@yahoo.com

\author{
Vernans V. Bautista, ${ }^{1}$ Rosario G. Monsalud ${ }^{2}$ and Akira Yokota ${ }^{1}$ \\ ${ }^{1}$ Institute of Molecular and Cellular Biosciences, The University of Tokyo, 1-1-1 Yayoi, Bunkyo-Ku, \\ Tokyo 113-0032, Japan \\ ${ }^{2}$ National Institute of Molecular Biology and Biotechnology, University of the Philippines - Los \\ Baños, 4031 College, Laguna, Philippines
}

Strain Yak96B $^{\mathrm{T}}$ was identified during a study to isolate nitrogen-fixing bacteria from leguminous plants thriving along the coast of Japan. The strain, probably belonging to the genus Devosia, was isolated along with strains belonging to the genus Rhizobium from a root nodule of the kudzu plant or Japanese arrowroot [Pueraria lobata (Willd.) Ohwi], which is native to and widely distributed in Japan. While the symbiotic relationship of Pueraria sp. with strains of the genera Bradyrhizobium and Mesorhizobium is well established (Abaidoo et al., 2000; Kwon et al., 2005; Germano et al., 2006), to the authors' knowledge, few studies, if any, have described the association of strains of the genus Devosia with the legume Pueraria. In this study, the relationships between strain Yak96B ${ }^{\mathrm{T}}$ and the Rhizobium spp. isolated and species of the genus Pueraria was not explored.

The genus Devosia (family Hyphomicrobiaceae) was created from the reclassification of Pseudomonas riboflavina as Devosia riboflavina (Nakagawa et al., 1996). At the time of

The GenBank/EMBL/DDBJ accession number for the 16S rRNA gene sequence of strain Yak96B' is $A B 361068$.

Three additional phylogenetic trees showing the position of strain Yak96B ${ }^{\top}$ in relation to recognized species of the genus Devosia and other members of the family Hyphomicrobiaceae are available with the online version of this paper. writing, the genus Devosia comprised eight recognized species: Devosia riboflavina (Nakagawa et al., 1996), Devosia neptuniae (Rivas et al., 2003), Devosia limi (Vanparys et al., 2005), Devosia soli (Yoo et al., 2006), Devosia insulae (Yoon et al., 2007), Devosia subaequoris (Lee, 2007), Devosia chinhatensis (Kumar et al., 2008) and Devosia geojensis (Ryu et al., 2008). Among these species, only $D$. neptuniae was isolated from an aquatic leguminous plant, Neptunia natans, and reported to possess the nitrogen-fixing (nifH) and the nodulating (nodD) symbiotic genes (Rivas et al., 2003). In contrast, the remaining species of the genus Devosia have been isolated from nonplant sources and do not possess these symbiotic genes. In this study, a strain of the genus Devosia isolated from a root nodule of a leguminous plant is reported but it was found to be devoid of the aforementioned symbiotic genes.

The main objective of this study was to determine the exact taxonomic position of strain Yak96B $^{\mathrm{T}}$ based on a polyphasic taxonomic approach, which included phylogenetic analysis of the 16S rRNA gene sequences, DNADNA hybridization and chemotaxonomic, physiological and morphological characterizations.

Strain Yak96B ${ }^{\mathrm{T}}$ was isolated from a root nodule of Pueraria lobata (Willd.) Ohwi collected from Yakushima Island, 
Kagoshima Prefecture, Japan. Cells were isolated by serial dilution using yeast extract-mannitol agar (Vincent, 1970) supplemented with Congo red $\left(15 \mathrm{mg} \mathrm{l}^{-1}\right)$ and Kabicidin (Nihon Seiyaku) as an antifungal agent. Plates were incubated at $28{ }^{\circ} \mathrm{C}$ for 4 days. Cells that grew on this medium formed small colonies ranging from 1 to $2 \mathrm{~mm}$ in diameter. The colonies had an entire margin and were slightly convex, shiny and light pink in colour.

D. riboflavina LMG $2277^{\mathrm{T}}$, D. neptuniae LMG $21357^{\mathrm{T}}$, D. limi LMG $22951^{\mathrm{T}}$, D. soli KACC $11509^{\mathrm{T}}$, D. insulae KCTC $12821^{\mathrm{T}}$, D. subaequoris KCTC $12772^{\mathrm{T}}$, D. chinhatensis CCM $7426^{\mathrm{T}}$ and Devosia geojensis $\mathrm{BD}-\mathrm{c} 194^{\mathrm{T}}$ were used as reference strains. The reference strains and strain Yak96B ${ }^{\mathrm{T}}$ were routinely cultured in tryptic soy agar (TSA) at $28{ }^{\circ} \mathrm{C}$ for $72 \mathrm{~h}$, with the exception of $D$. insulae KCTC $12821^{\mathrm{T}}$, which was grown at $25^{\circ} \mathrm{C}$ for 6 days, and D. subaequoris KCTC $12772^{\mathrm{T}}$, which was cultured on marine agar (MA) and incubated at $28{ }^{\circ} \mathrm{C}$ for $72 \mathrm{~h}$.

Cell morphology was determined by phase-contrast microscopy (BX60, Olympus) and transmission electron microscopy (TEM). The motility of the organism was assessed using a motility medium amended with tetrazolium chloride to provide contrast with the motility bands created by the organism. Flagellar staining (Heimbrook et al., 1989) and negative staining using TEM were used to elucidate the presence of the polar flagellum (Fig. 1). The Gram reaction was determined using $3 \%$ potassium hydroxide (Gregersen's method) and the BD Gram Stain kit (Becton, Dickinson and Co.).

The temperature range for the growth of strain $Y a k 96 \mathrm{~B}^{\mathrm{T}}$ was determined using TSA and cultures were incubated at

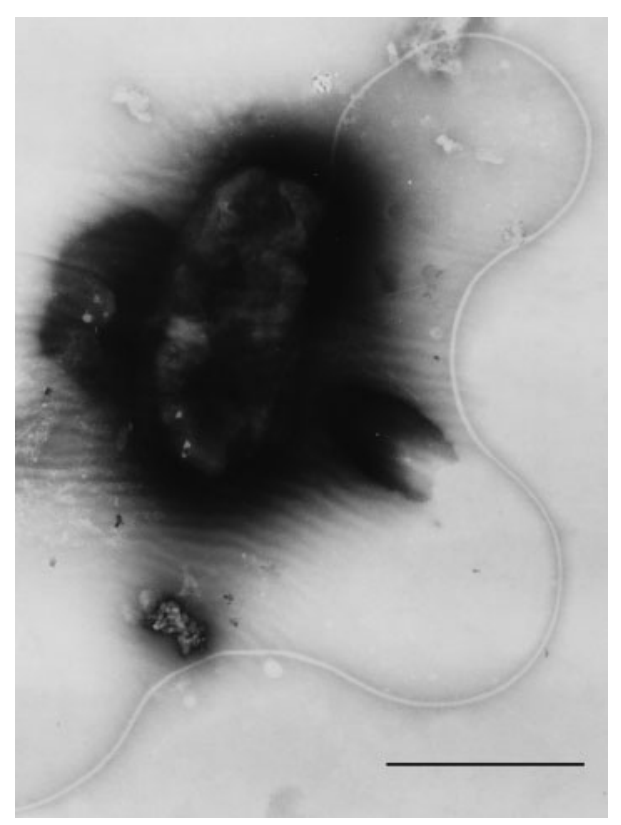

Fig. 1. Negatively stained cell of strain $\mathrm{Yak96B}^{\top}$. Bar, $1 \mu \mathrm{m}$.
$4,10,17,25,28,30,37$ and $45{ }^{\circ} \mathrm{C}$. Tolerance to $\mathrm{NaCl}$ was assessed by varying the concentration of $\mathrm{NaCl}$ from $0-6 \%$ $(\mathrm{w} / \mathrm{v})$ at increments of $0.5 \%(\mathrm{w} / \mathrm{v})$ on TSA. The $\mathrm{pH}$ range for growth was determined with filter-sterilized $(0.45 \mu \mathrm{m}$, Advantec) tryptic soy broth (TSB) adjusted from $\mathrm{pH} 4.0$ to $\mathrm{pH} 10.5$ with $0.5 \mathrm{pH}$ unit increments. Growth under anaerobic conditions was determined using an anaerobic chamber with AnaeroPack (Mitsubishi Gas Chemical Co., Inc.). Catalase and oxidase activities were determined using freshly prepared $3 \%$ hydrogen peroxide and cytochrome oxidase paper (Nissui Pharmaceutical Co. Ltd), respectively. The enzyme activity profiles of strain $Y^{2}$ ak $96 \mathrm{~B}^{\mathrm{T}}$ and the reference strains were assessed using API ZYM (bioMérieux) kits incubated at $28{ }^{\circ} \mathrm{C}$ for $7.5 \mathrm{~h}$. The substrate utilization profiles were determined by inoculating aliquots of cells into API $50 \mathrm{CH}$ (bioMérieux) strips and Biolog GN2 Microplates (Biolog) followed by incubation at $28{ }^{\circ} \mathrm{C}$ for $72 \mathrm{~h}$. The GN2 Microplates were read using a Biolog Micro Station (Biolog). The differential characteristics of strain $\mathrm{Yak} \mathrm{B}^{\mathrm{T}}$ and type strains of members of the genus Devosia are presented in Table 1.

Filter paper discs containing specified amounts of antibiotics were laid on lawns of cells (approx. $1 \times 10^{5}$ c.f.u. $\mathrm{ml}^{-1}$ based on the McFarland Standard) on TSA and MA plates to determine the antibiotic susceptibilities of strain Yak96B ${ }^{\mathrm{T}}$ and the reference strains. The antibiotics used in this study were ( $\mu$ g per disc unless otherwise stated): amikacin sulfate (30), ampicillin (10), carbenicillin disodium salt (100), cephalotin (30), chloramphenicol (30), ciproflacin (5), gentamicin sulfate (10), kanamycin (30), neomycin (30), oxacillin sodium monohydrate (30), polymyxin B sulfate (100 U), rifampicin (5), tetracycline hydrochloride (30) and vancomycin hydrochloride (30).

The isoprenoid quinones and DNA G $+\mathrm{C}$ content were determined by the HPLC method using a 5C-18AR Cosmosil packed column (Nacalai Tesque) as described by Collins \& Jones (1981) and Mesbah et al. (1989), respectively. The major $(85 \%)$ respiratory quinone type of strain Yak96B $^{\mathrm{T}}$ was Q10, which makes it similar to $D$. riboflavina, D. neptuniae, D. limi, D. soli, and D. geojensis, but not $D$. insulae, in which Q11 predominates (Yoon et al., 2007). The DNA G + C content was $65.3 \mathrm{~mol} \%$, which was within the range of 59.5-66.2 mol\% included in the emended description of the genus Devosia (Yoon et al., 2007). The polar lipids were determined by two-dimensional TLC according to Minnikin et al. (1979). The polar lipids of strain Yak96B ${ }^{\mathrm{T}}$ were composed of phosphatidylglycerol and diphosphatidylglycerol.

Cells that had been subcultured twice on TSA (Difco) at $28{ }^{\circ} \mathrm{C}$ for $72 \mathrm{~h}$ were used for fatty acid extraction with the Sherlock Microbial Identification System (MIDI) and analysed in a 6890 Series GC System equipped with a 7860 Series Injector (Agilent). The fatty acid profile of strain Yak96B ${ }^{\mathrm{T}}$ was very similar to those of the other type strains of the genus Devosia. However, significant differences in the amounts of individual fatty acids clearly showed that 
Table 1. Some characteristics of strain $\mathrm{Yak} 96 \mathrm{~B}^{\top}$ and closely related species of the genus Devosia

Strain: 1, Yak96B ${ }^{\mathrm{T}}$; 2, D. riboflavina LMG $2277^{\mathrm{T}}$; 3, D. neptuniae LMG $21357^{\mathrm{T}}$; 4, D. limi $22951^{\mathrm{T}}$; 5, D. soli KACC $11509^{\mathrm{T}}$; 6, D. insulae $\mathrm{KCTC}$ $12821^{\mathrm{T}} ; 7$, D. subaequoris KCTC $12772^{\mathrm{T}} ; 8$, D. chinhatensis CCM $7426^{\mathrm{T}} ; 9$, D. geogensis BD-c194 ${ }^{\mathrm{T}}$. All strains were incubated at $28{ }^{\circ} \mathrm{C}$ except $D$. insulae KCTC $12821^{\mathrm{T}}$, which was incubated at $25{ }^{\circ} \mathrm{C}$. All data were obtained from this study. The DNA G+C content was obtained from the respective authors of the descriptions of the type strains (except for D. chinhatensis CCM $7426^{\mathrm{T}}$ ). +, Positive; -, negative; w, weak; s, sensitive; $\mathrm{R}$, resistant.

\begin{tabular}{|c|c|c|c|c|c|c|c|c|c|}
\hline Characteristic & 1 & 2 & 3 & 4 & 5 & 6 & 7 & 8 & 9 \\
\hline$N$-Acetylglucosamine & - & + & - & - & - & - & - & $\mathrm{w}$ & + \\
\hline L-Arabinose & + & + & + & + & - & - & - & + & - \\
\hline D-Mannose & + & + & + & + & - & - & $\mathrm{w}$ & + & + \\
\hline D-Mannitol & + & + & + & - & - & - & $\mathrm{w}$ & + & + \\
\hline Acid phosphatase & + & + & + & + & + & + & - & + & + \\
\hline Cystine arylamidase & - & - & - & - & - & - & - & $\mathrm{w}$ & - \\
\hline Esterase (C4) & $\mathrm{w}$ & $\mathrm{w}$ & - & + & + & - & + & + & + \\
\hline Esterase lipase (C8) & $\mathrm{w}$ & + & + & + & + & $\mathrm{w}$ & + & + & + \\
\hline$\alpha$-Fucosidase & - & + & + & - & - & $\mathrm{w}$ & - & - & - \\
\hline Lipase (C14) & - & - & - & $\mathrm{w}$ & - & - & - & - & - \\
\hline$\alpha$-Mannosidase & + & + & + & - & + & - & - & - & - \\
\hline Naphthol-AS-BI-phosphohydrolase & $\mathrm{w}$ & - & $\mathrm{w}$ & - & - & $\mathrm{w}$ & + & - & $\mathrm{w}$ \\
\hline Trypsin & + & + & - & - & - & - & + & + & + \\
\hline Valine arylamidase & - & - & - & + & + & - & - & + & w \\
\hline \multicolumn{10}{|l|}{ Antibiotic susceptibility } \\
\hline Chloramphenicol & s & s & s & s & s & s & s & s & $\mathrm{R}$ \\
\hline Gentamicin & $\mathrm{R}$ & s & $\mathrm{R}$ & s & s & $\mathrm{R}$ & $\mathrm{R}$ & $\mathrm{R}$ & $\mathrm{R}$ \\
\hline Kanamycin & $\mathrm{R}$ & $\mathrm{R}$ & $\mathrm{R}$ & s & $\mathrm{R}$ & $\mathrm{R}$ & $\mathrm{R}$ & $\mathrm{R}$ & $\mathrm{R}$ \\
\hline Neomycin & s & s & s & s & s & $\mathrm{R}$ & $\mathrm{R}$ & $\mathrm{R}$ & s \\
\hline Oxacillin & $\mathrm{R}$ & s & s & s & s & s & $\mathrm{R}$ & s & s \\
\hline
\end{tabular}

strain Yak96B ${ }^{\mathrm{T}}$ represents a novel species of the genus Devosia (Table 2 ). The predominant fatty acids $(>5 \%)$ were 11-methyl $\mathrm{C}_{18: 1} \omega 7 c \quad(35.0 \%), \quad \mathrm{C}_{16: 0} \quad(22.4 \%)$, $\mathrm{C}_{18: 1} \omega 7 c(21.8 \%), \mathrm{C}_{19: 0}$ cyclo $\omega 8 c(6.8 \%)$ and $\mathrm{C}_{18: 0}$ $(5.4 \%)$. Minor fatty acids, namely $\mathrm{C}_{13: 0}$ iso $3-\mathrm{OH}, \mathrm{C}_{17: 0}$ iso, $\mathrm{C}_{18: 1} \omega 9 \mathrm{c}$, and ECL 18.814, which have been found in other species of the genus Devosia, were not detected in strain Yak96B $^{\mathrm{T}}$.

The DNA template for PCR amplification of the 16S rRNA gene was prepared according to the method of Hiraishi (1992). The gene was amplified by PCR primers $8 \mathrm{~F}$ and 1510R (Brosius et al., 1978). The amplified PCR products were cleaned using PEG 6000 and $70 \%$ ethanol. The refined PCR products were directly sequenced with the use of a BigDye Terminator v3.1 Cycle Sequencing kit (Applied Biosystems) using the conserved 16S rRNA gene primers indicated by Kurahashi \& Yokota (2002). BigDye PCR products were cleaned with CleanSEQ (Agencourt) and sequenced in an ABI PRISM 310 Genetic Analyzer (Applied Biosystems).

The sequences were edited and aligned in BioEdit v7.0.5.3 (Hall, 1999) and compared with the sequences obtained from GenBank and the DNA Data Bank of Japan (DDBJ). Multiple alignments of the sequences were carried out in CLUSTAL_X v1.83 (Thompson et al., 1997). Alignment gaps and ambiguous bases were not taken into consideration when the bases of 16S rRNA gene nucleotides were compared. The phylogenetic and molecular evolutionary analyses were determined using MEGA software v4 (Tamura et al., 2007). Phylogenetic trees were constructed using the neighbour-joining method (Saitou \& Nei, 1987) utilizing the Kimura two-parameter model (Kimura, 1983), JukesCantor (Jukes \& Cantor, 1969), maximum-composite likelihood and maximum-parsimony algorithms (see 
Table 2. Fatty acid profiles of strain $\mathrm{Yak} 96 \mathrm{~B}^{\top}$ and the type strains of the genus Devosia

Strains: 1, Yak96B ${ }^{\mathrm{T}}$; 2, D. riboflavina LMG $2277^{\mathrm{T}}$; 3, D. neptuniae LMG $21357^{\mathrm{T}}$; 4, D. limi LMG 22951 ${ }^{\mathrm{T}}$; 5, D. soli KACC $11509^{\mathrm{T}}$; 6, D. insulae KCTC $12821^{\mathrm{T}}$; 7, D. subaequoris KCTC $12772^{\mathrm{T}}$; 8 , D. chinhatensis CCM $7426^{\mathrm{T}} ; 9$, D. geogensis BD-c194 ${ }^{\mathrm{T}}$. Strains $1-5$ and $8-9$ were grown with TSA at $28{ }^{\circ} \mathrm{C}$ for $72 \mathrm{~h}$. Strain 6 was grown with TSA at $25{ }^{\circ} \mathrm{C}$ for 6 days and strain 7 was grown on MA at $28{ }^{\circ} \mathrm{C}$ for 72 h. - , Not detected.

\begin{tabular}{|c|c|c|c|c|c|c|c|c|c|}
\hline Fatty acid & 1 & 2 & 3 & 4 & 5 & 6 & 7 & 8 & 9 \\
\hline $\mathrm{C}_{10: 0} 3-\mathrm{OH}$ & 0.6 & 1.2 & 0.4 & 1.1 & 1.1 & - & - & - & - \\
\hline $\mathrm{C}_{13: 0}$ iso $3-\mathrm{OH}$ & - & - & - & - & - & 1.1 & - & - & - \\
\hline $\mathrm{C}_{16: 0}$ & 22.4 & 18.7 & 20.6 & 11.8 & 18.1 & 14.1 & 8.7 & 12.6 & 17.4 \\
\hline $\mathrm{C}_{17: 0}$ cyclo & 0.4 & 0.6 & 2.4 & 0.5 & - & - & 0.2 & - & - \\
\hline $\mathrm{C}_{17: 0}$ iso & - & - & - & - & - & 13.4 & - & - & - \\
\hline $\mathrm{C}_{17: 0}$ & 2.0 & - & 0.3 & 0.5 & - & 2.2 & 0.8 & 3.2 & 3.0 \\
\hline $\mathrm{C}_{18: 1} \omega 9 c$ & - & - & - & - & - & 1.9 & - & - & - \\
\hline $\mathrm{C}_{18: 1} \omega 7 c$ & 21.8 & 47.2 & 24.5 & 33.8 & 55.4 & 17.1 & 57.7 & 55.4 & 26.3 \\
\hline $\mathrm{C}_{18: 0} 3-\mathrm{OH}$ & 2.9 & - & 2.9 & 3.2 & 2.4 & - & 2.5 & 2.2 & - \\
\hline $\mathrm{C}_{18: 0}$ & 5.4 & 3.6 & 4.6 & 10.8 & 2.5 & 4.6 & 4.8 & 3.5 & 11.3 \\
\hline 11-methyl $\mathrm{C}_{18: 1} \omega 7 c$ & 35.0 & 24.8 & 31.8 & 30.5 & 17.3 & 31.0 & 20.9 & 19.8 & 30.6 \\
\hline $\mathrm{C}_{19: 0}$ cyclo $\omega 8 \mathrm{c}$ & 6.8 & 1.5 & 8.8 & 2.7 & 0.4 & 1.7 & 1.0 & - & 3.7 \\
\hline ECL 14.959 & 1.2 & - & 1.2 & 1.2 & - & - & 0.8 & - & - \\
\hline ECL 18.814 & - & - & - & - & - & 11.0 & - & - & 7.4 \\
\hline Summed feature $3^{\star}$ & 0.6 & 2.2 & 1.8 & 2.2 & 1.5 & - & 2.3 & 1.1 & - \\
\hline
\end{tabular}

${ }^{*}$ Summed feature 3 comprised $\mathrm{C}_{16: 1} \omega 7 c$ and/or iso- $\mathrm{C}_{15: 0} 2-\mathrm{OH}$.

Supplementary Figs S1, S2 and S3 in IJSEM Online). Evolutionary distances were computed using the Kimura two-parameter model and bootstrap values based on 1000 replications were selected in the program. Phylogenetic analysis based on 16S rRNA gene sequences (1356 bp) indicated that strain $\mathrm{Yak}_{96} \mathrm{~B}^{\mathrm{T}}$ was positioned within the genus Devosia (Fig. 2). It was closely related to D. neptuniae $\mathrm{J} 1^{\mathrm{T}}$ and $D$. chinhatensis IPL $18^{\mathrm{T}}$ with sequence similarities of $98.1 \%$ and $97.8 \%$, respectively. The novel strain showed $\leqslant 97 \%$ gene sequence similarities when compared with the other recognized species of the genus Devosia.

DNA-DNA hybridization was determined by using photobiotin-labelled probes in a polystyrene 96-well plate (NuncMaxisorp) as described by Ezaki et al. (1989). The hybridization was performed with five replications and the hybridization temperature was $55{ }^{\circ} \mathrm{C}$. The mean DNADNA relatedness values of strain Yak $96 \mathrm{~B}^{\mathrm{T}}$ to $D$. neptuniae LMG $21357^{\mathrm{T}}$ and D. chinhatensis CCM $7426^{\mathrm{T}}$ were $53.6 \%$ and $34 \%$, respectively, which were lower than the $70 \%$ value considered as the threshold for the delineation of genomic species (Stackebrandt \& Goebel, 1994). These hybridization values clearly revealed that strain Yak96B ${ }^{\mathrm{T}}$ represents a separate and a novel species of the genus Devosia.

The presence of the nitrogen-fixing $(n i f H)$ and nodulation (nodD) genes was tested using the primers and PCR conditions described by Rivas et al. (2002). The DNA templates of strain Yak96B ${ }^{\mathrm{T}}$, D. neptuniae LMG $21357^{\mathrm{T}}$ and Rhizobium leguminosarum IAM $12609^{\mathrm{T}}$ (as positive controls) for PCRs were prepared using the method of Marmur (1961), the Sarkosyl method (Rivas et al., 2002) and the boiling method followed by plasmid DNA extraction with a QuickLyse Miniprep kit (Qiagen). The control bacterial strains showed specific bands for both nifH and nodD genes, but no bands were observed for strain Yak96B ${ }^{\mathrm{T}}$. An infection assay was conducted according to the method of Somasegaran \& Hoben (1994) using Macroptilium atropurpureum (common name Siratro) as the host plant to determine the nodulation ability of the test strains. Strain Yak $96 B^{\mathrm{T}}$ failed to nodulate with $M$. atropurpureum.

\section{Description of Devosia yakushimensis sp. nov.}

Devosia yakushimensis (ya.ku.shi.men'sis. N.L. fem. adj. yakushimensis pertaining to Yakushima, from where the organism was isolated).

Cells are obligately aerobic, Gram-negative, motile rods of $1.2-2.0 \mu \mathrm{m}$ long and $0.4-0.6 \mu \mathrm{m}$ wide that are nonendospore-forming and possess a polar flagellum. Colonies on TSA are circular with an entire margin (1$2 \mathrm{~mm}$ in diameter) and are convex, shiny and beige in colour after 2 days of incubation at $28{ }^{\circ} \mathrm{C}$. Does not require $\mathrm{NaCl}$ for growth, but tolerates up to $2.5 \%(\mathrm{w} / \mathrm{v}) \mathrm{NaCl}$. The $\mathrm{pH}$ range for growth is narrow at $\mathrm{pH}$ 5.5-7.0; good growth occurs at $\mathrm{pH} 7.0$. The major $(85 \%)$ respiratory quinone is ubiquinone 10 (Q10). Polar lipids consist of phosphatidylglycerol and diphosphatidylglycerol. The predominant fatty acids $(>5 \%)$ are 11-methyl $\mathrm{C}_{18: 1} \omega 7 c, \mathrm{C}_{16: 0}$, $\mathrm{C}_{18: 1} \omega 7 c, \mathrm{C}_{19: 0}$ cyclo $\omega 8 c$ and $\mathrm{C}_{18: 0}$. Positive in tests for the assimilation of $\mathrm{D}$ - and L-arabinose, D-ribose, D- and Lxylose, D-galactose, D-glucose, D-mannose, L-rhamnose, aesculin, salicin, cellobiose, maltose, D-lactose (bovine 


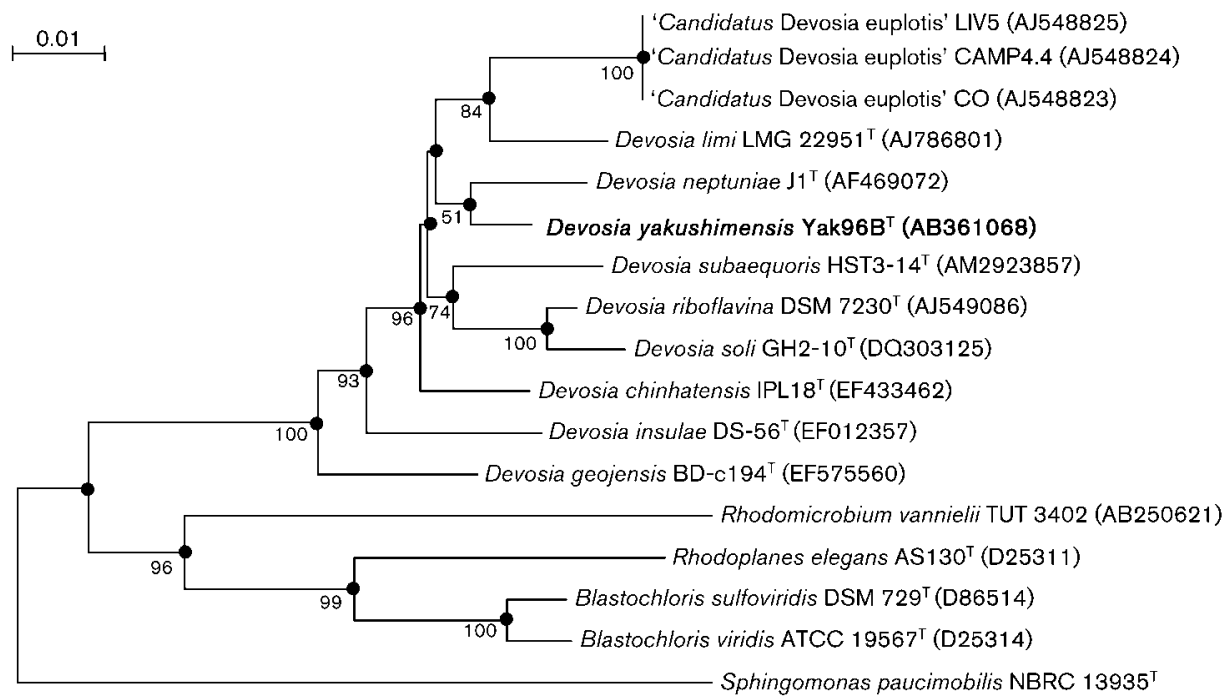

Fig. 2. Neighbour-joining (Saitou \& Nei, 1987) phylogenetic tree using the Kimura two-parameter model (Kimura, 1983), based on 16S rRNA gene sequences showing the taxonomic position of strain Yak96B ${ }^{\top}$ with respect to recognized species of the genus Devosia and some members of the family Hyphomicrobiaceae. Filled circles indicate generic branches that were also recovered by the Jukes-Cantor model (Jukes \& Cantor, 1969) and maximum-composite likelihood algorithms. Bootstrap values $>50 \%$ are shown as percentages of 1000 replications. GenBank accession numbers are given in parentheses. The 16S rRNA sequence for $S$. paucimobilis was obtained from the NITE-NBRC website. Bar, 1 substitution per 100 nucleotides.

origin), D-melibiose, gentiobiose, D-lyxose, D-tagatose, D- and L-fucose, potassium 5-ketogluconate, D-fructose, L-fucose, myo-inositol, raffinose, D-sorbitol, trehalose and D-gluconic acid. Produces urease, catalase, oxidase, alkaline phosphatase, leucine arylamidase, trypsin, acid phosphatase, $\alpha$ - and $\beta$-galactosidase, $\alpha$ - and $\beta$-glucosidase, $N$-acetyl$\beta$-glucosaminidase and $\alpha$-mannosidase, but not lipase (C14), valine arylamidase, cystine arylamidase, $\alpha$-chymotrypsin, $\beta$-glucuronidase or $\alpha$-fucosidase. Weak enzyme activity for esterase (C4), esterase lipase (C8) and naphthol-AS-BI-phosphohydrolase. Susceptible to amikacin, ampicillin, carbenicillin, cephalotin, chloramphenicol, neomycin, rifampicin, tetracycline and vancomycin, but resistant to ciproflacin, gentamicin, kanamycin, oxacillin and polymyxin $\mathrm{B}$.

The type strain, Yak96B ${ }^{\mathrm{T}}\left(=\mathrm{KCTC} 22147^{\mathrm{T}}=\mathrm{NBRC} 103855^{\mathrm{T}}\right.$ $=\mathrm{LMG} 24299^{\mathrm{T}}$ ), was isolated from a root nodule of the kudzu plant [Pueraria lobata (Willd.) Ohwi] thriving on the coast of Yakushima Island, Kagoshima Prefecture, Japan. The DNA $\mathrm{G}+\mathrm{C}$ content of the type strain is $65.3 \mathrm{~mol} \%$.

\section{Acknowledgements}

The authors are deeply grateful to the Salt Science Research Foundation for the generous research funds, to the Ministry of Education, Culture, Sports, Science and Technology of Japan for the scholarship grant to the senior author, to Professor Karen A. Salandanan for valuable suggestions, and to the BCM/LMG, CCM and Dr Che Ok Jeon for generously providing the strains of $D$. neptuniae LMG $21357^{\mathrm{T}}$, Devosia chinhatensis CCM $7426^{\mathrm{T}}$ and D. geojensis $\mathrm{BD}-\mathrm{c} 194^{\mathrm{T}}$, respectively.

\section{References}

Abaidoo, R. C., Keyser, H. H., Singleton, P. W. \& Borthakur, D. (2000). Bradyrhizobium spp. (TGx) isolates nodulating the new soybean cultivars in Africa are diverse and distinct from bradyrhizobia that nodulate North American soybeans. Int J Syst Evol Microbiol 50, 225-234.

Brosius, J., Palmer, M. L., Kennedy, P. J. \& Noller, H. F. (1978). Complete nucleotide sequence of a $16 \mathrm{~S}$ ribosomal RNA gene from Escherichia coli. Proc Natl Acad Sci U S A 75, 4801-4805.

Collins, M. D. \& Jones, D. (1981). A note on the separation of natural mixtures of bacterial ubiquinones using reverse-phase partition thinlayer chromatography and high performance liquid chromatography. J Appl Bacteriol 51, 129-134.

Ezaki, T., Hashimoto, Y. \& Yabuuchi, E. (1989). Fluorometric deoxyribonucleic acid-deoxyribonucleic acid hybridization in microdilution wells as an alternative to membrane filter hybridization in which radioisotopes are used to determine genetic relatedness among bacterial strains. Int J Syst Bacteriol 39, 224-229.

Germano, M. G., Menna, P., Mostasso, F. L. \& Hungria, M. (2006). RFLP analysis of the rRNA operon of a Brazilian collection of bradyrhizobial strains from 33 legume species. Int J Syst Evol Microbiol 56, 217-229.

Hall, T. A. (1999). BioEdit: a user-friendly biological sequence alignment editor and analysis program for Windows 95/98/NT. Nucleic Acids Symp Ser 41, 95-98.

Heimbrook, M. E., Wang, W. L. L. \& Campbell, G. (1989). Staining bacterial flagella easily. J Clin Microbiol 27, 2612-2615.

Hiraishi, A. (1992). Direct automated sequencing of $16 \mathrm{~S}$ rDNA amplified by polymerase chain reaction from bacterial cultures without DNA purification. Lett Appl Microbiol 15, 210-213.

Jukes, T. \& Cantor, C. R. (1969). Evolution of protein molecules. In Mammalian Protein Metabolism, vol. 3, pp. 21-132. Edited by H. N. Munro. New York: Academic Press. 
Kimura, M. (1983). In The Neutral Theory of Molecular Evolution, pp. 41-46. London: Cambridge University Press.

Kumar, M., Verma, M. \& Lal, R. (2008). Devosia chinhatensis sp. nov., isolated from a hexachlorocyclohexane $(\mathrm{HCH})$ dump site in India. Int J Syst Evol Microbiol 58, 861-865.

Kurahashi, M. \& Yokota, A. (2002). A preliminary report of phylogenetic diversity of bacterial strains isolated from marine creatures. J Gen Appl Microbiol 48, 251-259.

Kwon, S.-W., Park, J.-Y., Kim, J.-S., Kang, J.-W., Cho, Y.-H., Lim, C.-K., Parker, M. A. \& Lee, G.-B. (2005). Phylogenetic analysis of the genera Bradyrhizobium, Mesorhizobium, Rhizobium and Sinorhizobium on the basis of $16 \mathrm{~S}$ rRNA gene and internally transcribed spacer region sequences. Int J Syst Evol Microbiol 55, 263-270.

Lee, S. D. (2007). Devosia subaequoris sp. nov., isolated from beach sediment. Int J Syst Evol Microbiol 57, 2212-2215.

Marmur, J. (1961). A procedure for the isolation of deoxyribonucleic acid from microorganisms. J Mol Biol 3, 208-218.

Mesbah, M., Premachandran, U. \& Whitman, W. B. (1989). Precise measurement of the $\mathrm{G}+\mathrm{C}$ content of deoxyribonucleic acid by highperformance liquid chromatography. Int J Syst Bacteriol 39, 159-167.

Minnikin, D. E., Collins, M. D. \& Goodfellow, M. (1979). Fatty acid and polar lipid composition in the classification of Cellulomonas, Oerskovia and related taxa. J Appl Bacteriol 47, 87-95.

Nakagawa, Y., Sakane, T. \& Yokota, A. (1996). Transfer of "Pseudomonas riboflavina" (Foster 1944), a Gram-negative, motile rod with long-chain 3-hydroxy fatty acids, to Devosia riboflavina gen. nov., nom. rev. Int J Syst Bacteriol 46, 16-22.

Rivas, R., Velázquez, E., Willems, A., Vizcanino, N., Subba-Rao, N. S., Mateos, P. F., Gillis, M., Dazzo, F. B. \& Martinez-Molina, E. (2002). A new species of Devosia that forms a unique nitrogen-fixing rootnodule symbiosis with the aquatic legume Neptunia natans (L.f.) Druce. Appl Environ Microbiol 68, 5217-5222.

Rivas, R., Willems, A., Subba-Rao, N. S., Vizcanino, N., Mateos, P. F., Dazzo, F. B., Kroppenstedt, R. M., Martinez-Molina, E., Gillis, M. \&
Velázquez, E. (2003). Description of Devosia neptuniae sp. nov. that nodulates and fixes nitrogen in symbiosis with Neptunia natans, an aquatic legume from India. Syst Appl Microbiol 26, 47-53.

Ryu, S. H., Chung, B. S., Le, N. T., Jang, H. H., Yun, P.-Y., Park, W. \& Jeon, C. O. (2008). Devosia geojensis sp. nov., isolated from dieselcontaminated soil in Korea. Int J Syst Evol Microbiol 58, 633-636.

Saitou, N. \& Nei, M. (1987). The neighbor-joining method: a new method for reconstructing phylogenetic trees. Mol Biol Evol 4, 406425.

Somasegaran, P. \& Hoben, H. J. (1994). Handbook for Rhizobia: Methods in Legume-Rhizobium Technology. New York: Springer.

Stackebrandt, E. \& Goebel, B. M. (1994). Taxonomic note: a place for DNA-DNA reassociation and 16S rRNA sequence analysis in the present species definition in bacteriology. Int J Syst Bacteriol 44, 846849.

Tamura, K., Dudley, J., Nei, M. \& Kumar, S. (2007). MEGA4: molecular evolutionary genetics analysis (MEGA) software version 4.0. Mol Biol Evol 24, 1596-1599.

Thompson, J. D., Gibson, T. J., Plewniak, F., Jeanmougin, F. \& Higgins, D. G. (1997). The CLUSTAL_X windows interface: flexible strategies for multiple sequence alignment aided by quality analysis tools. Nucleic Acids Res 25, 4876-4882.

Vanparys, B., Heylen, K., Lebbe, L. \& Vos, P. D. (2005). Devosia limi sp. nov., isolated from a nitrifying inoculum. Int J Syst Evol Microbiol 55, 1997-2000.

Vincent, J. M. (1970). A Manual for the Practical Study of the Root Nodule Bacteria. IBP Handbook no. 15. Oxford: Blackwell Scientific.

Yoo, S.-H., Weon, H.-Y., Kim, B.-Y., Hong, S.-B., Kwon, S.-W., Cho, Y.-H., Go, S.-J. \& Stackebrandt, E. (2006). Devosia soli sp. nov., isolated from greenhouse soil in Korea. Int J Syst Evol Microbiol 56, 2689-2692.

Yoon, J.-H., Kang, S.-J. \& Park, S. (2007). Devosia insulae sp. nov., isolated from soil, and emended description of the genus Devosia. Int J Syst Evol Microbiol 57, 1310-1314. 